\title{
PEMBINAAN KAJIAN KEAGAMAAN BERBASIS KARAKTER ISLAMI PADA MAJELIS TAKLIM LOWOKWARU
}

\author{
Danial Hilmi, Nur Toifah, Erna Herawati ${ }^{*}$ \\ ${ }^{1}$ UIN Maulana Malik Ibrahim Malang
}

\begin{abstract}
This study aims to provide an overview related to the development of religious culture among Majelis Taklim Tunggul Wulung, Lowokwaru, Malang City, where urban communities are in fact educated communities, but are not accompanied by adequate religious understanding. In the meantime, fostering religious studies is important to form Islamic societies. The method used is Participatory Action Research, a study that is accompanied by concrete actions through a form of active participation to be part of the community with the aim of ultimately changing patterns that are less productive. The form of religious culture development in this fostering is carried out counseling and mentoring religious traditions by way of routine study of kitab Salaf as well as simulating the practice procedures for carrying out religious traditions that are in line with Islamic values and emphasizing good attitudes and character. As for the results of this coaching that there is a change in society about increasing religious knowledge and insights specifically womanhood which is always a daily problem, and this coaching is running intensively and is always followed by most residents.
\end{abstract}

Keywords: Coaching, Religious Study, Characterized

Abstrak: Kajian ini bertujuan untuk memberikan gambaran terkait
pembangunan budaya religius di kalangan Majelis Taklim Tunggul
Wulung Lowokwaru Kota Malang dimana masyarakat perkotaan yang
notabene merupakan masyarakat yang berpendidikan, namun tidak
dibarengi dengan pemahaman keagamaan yang memadai. Dalam
pada itu, pembinaan kajian keagamaan menjadi penting untuk
membentuk masyarakat berkarakter Islami. Adapun metode yang

*Korespondensi Penulis: danialhilmi@gmail.com 
dipergunakan yaitu Participatory Action Research yaitu sebuah penelitian yang disertai dengan tindakan nyata melalui bentuk partisipasi aktif menjadi bagian dari masyarakat dengan tujuan akhir mengubah pola yang kurang menjadi lebih produktif. Adapun bentuk pembangunan budaya religi dalam pembinaan ini yaitu dilakukan penyuluhan dan pendampingan tradisi keagamaan dengan cara pengajian rutin kitab salaf serta simulasi praktik tata cara menjalankan tradisi keagamaan yang sejalan dengan nilai-nilai Islam serta menekankan sikap dan karakter yang baik. Sementara hasil dari pembinaan ini adalah terdapat perubahan di masyarakat tentang peningkatan pengetahuan dan wawasan keagamaan terkhusus kewanitaan yang selalu menjadi persoalan sehari-har, dan pembinaan ini berjalan intensif serta senantiasa diikuti oleh sebagian besar warga.

\section{Kata Kunci: Pembinaan, Kajian Keagamaan, Berkarakter}

\section{A. Pendahuluan}

Majelis taklim merupakan ajang silaturrahmi bagi segenap masyarakat dengan pembinaan kajian keagamaan yang kental dengan bentuk muhadharah yang berguna untuk menimba ilmu agama Islam dengan cara mendengarkan ceramah maupun melalui pengajian kitab. Dalam pada itu, keberadaan majelis taklim kian hari kian diminati masyarakat di tengah kehidupan yang penuh persaingan dan arus modernitas yang tiada hentinya.Jalan keluar terhadap setiap persoalan kehidupan hendaknya kembali kepada agama yang menjadi tuntunan dalam berperilaku dalam masyarakat.

Masyarakat Tunggul Wulung tergolong masyarakat yang majemuk dengan perpaduan antara penduduk asli dan pendatang yang terus bertambah dengan hadirnya pemukiman baru dalam bentuk perumahan maupun mahasiswa yang juga merambah wilayah Tunggul Wulung yang tidak bisa tidak harus diperhatikan dalam ikut serta menjadi bagian dari sebuah masyarakat. Dalam pada itu, majelis taklim yang giat dilakukan di masyarakat tersebut membawa bentuk semangat religius yang menjadi bagian dari perilaku masyarakat Tunggul Wulung.

Pembentukan masyarakat yang religius dijadikan acuan sikap spiritual yang baik dimana sendi-sendi kehidupan yang agamis dapat dilansanakan dengan 
Pembinaan Kajian Keagamaan Berbasis Karakter Islam Pada Majelis Taklim Lowokwaru

sebaik-baiknya. Perilaku dan interaksi sehari-hari yang baik dengan mencerminkan nilai-nilai agama akan menjadi indikator keberhasilan sebuah pendidikan keagamaan pada suatu masyarakat. Peran serta tokoh agama dan masyarakat akan memberikan andil yang sangat besar dalam merintis dan merawat kehidupan keberagamaan yang sejalan dengan nuansa Islami.

Seringkali didapati dalam sebuah masyarakat yang tergolong pendatang, tidak selalu hidup hedonis dan tidak mengenal kehidupan bertetangga. Namun saat itu, kerap ditemukan banyak perumahan yang dahulu terkenal dengan kehidupan individual ternyata saat ini justru datang dengan membawa semangat kehidupan bertetangga yang tinggi sehingga dapat terlaksana kegiatan keagamaan yang baik. Disamping itu, corak kehidupan bagi golongan masyarakat tersebut memberikan pola interaksi yang beragam dan relevan dengan kondisi zaman kini.

Perubahan pola interaksi dan perilaku dalam hidup bermasyarakat muncul kembali di era kini dengan banyaknya tradisi keagamaan yang terbentuk dalam sebuah majelis taklim. Sebagaimana hasil observasi dan penjajakan yang dilakukan, diperoleh keterangan bahwa masyarakat antusias dalam mengikuti kegiatan keagamaan terutama di era modernitas yang membutuhkan ketenangan batin yang penuh dengan persaingan. Oleh karena itu, penerapan dan program pengajian dalam bentuk kajian al-Qur'an dan pemahaman maknanya menjadi sebuah hal yang urgen agar masyarakat tidak awam dalam menjalankan akidah dan keharusan yang dilakukan dalam beragama Islam. Begitu juga kajian kebahasaan sebagai fondasi penting dalam memahami kandungan al-Qur'an tidak terbantahkan lagi menjadi hal yang penting. Oleh karena itu, kajian ini tidak hanya membekali majelis taklim dengan pengajian keagamaan murni, namun juga kajian kebahasaan untuk membangun budaya sadar religi dengan kemampuan untuk mengenal dan memahami dari bahasanya langsung.

Namun persoalan yang ditemui adalah minimnya kajian agama yang ada di majelis taklim Tunggul Wulung terutama dalam bentuk kajian kandungan makna al-Qur'an dan pengenalan kajian kebahasaan secara langsung sehingga berdampak 
pengamalan secara individu belum sempurna dilaksanakan. Pembinaan kajian keagamaan dan kebahasaan akan memberikan ruang positif pada terciptanya kehidupan yang beretika dan mencerminkan kesiapan dalam menghadapi dan membentuk generasi mendatang yang berkarakter Islami.

Adapun fokus pembinaan ini adalah untuk memberikan bekal keagamaan yang cukup kepada masyarakat dengan menambahkan kemampuan kebahasaannya untuk menjawab keraguan dan kekurangan dalam memahami agama secara utuh. Oleh karena itu melalui kajian, ini diharapkan masyarakat terutama majelis taklim memiliki pengetahuan agama yang cukup dengan memahami kandungan al-Qur'an yang memadai dengan penyajian materi yang menarik dan menyenangkan untuk memberikan bekas yang dapat dijalankan secara nyata dan produktif untuk keberlanjutan pola hidup agamis yang berkarakter Islami.

Masyarakat Tunggul Wulung Kecamatan Lowokwaru memiliki jumlah penduduk yang beragam serta mengalami penambahan warga dari tahun ke tahun, begitu juga pemukiman yang semakin banyak dan memperkaya kompleksitas perilaku di masyarakat. Adapun Majelis Taklim yang berjalan di masyarakat Tunggul Wulung memiliki peran yang signifikan dalam meningkatkan budaya spiritualitas yang tinggi dengan dibarengi pembangunan masyarakat yang variatif.

Saat ini kondisi majelis taklim semakin ramai dengan kegiatan keagamaan, hal itu sangat dimungkinkan mengingat banyaknya warga yang haus akan pendidikan keagamaan serta penanaman nilai spiritual yang memadai. Bertambahnya jumlah penduduk dan masyarakat pendatang, mengairahkan semangat untuk menuntut ilmu agama yang mencukupi sebagai bekal dalam menjalan semangat hidup yang serba modern.

Di satu sisi, banyaknya mahasiswa yang bermukim di Tunggul Wulung dengan berdirinya rumah kos-kosan, maka bertambah pula varian masyarakat yang berada di wilayah tersebut. Oleh karena itu, dituntut adanya partisipasi yang 
lebih untuk meningkatkan dan membudayakan semangat keagamaan yang dapat tercermin di wilayah yang menginginkan adanya pesan moral yang religius.

Dalam pada itu, keseriusan masyarakat untuk mencita-citakan semangat religius yang tinggi tidak dibarengi dengan dorongan untuk menanamkan nilainilai keagamaan. Tampak sekali masyarakat kerap mengikuti pengajian dan majelis taklim di luar wilayahnya demi untuk mendapatkan ilmu pengetahuan keagamaan yang baik. Oleh karena itu, dibutuhkan penanaman nilai keagamaan yang memadai melalui sebuah kajian keislaman baik itu dalam bentuk pengajian di masjid maupun di majelis taklim secara langsung dalam bentuk ceramah maupun pengajian kitab kuning yang akan memberikan semangat beribadah dan beramal shaleh yang sesuai dengan pesan agama Islam.

Pembinaan kegiatan keagamaan melalui kajian keislaman di masyarakat Tunggul Wulung Kecamatan Lowokwaru didorong untuk meningkatkan kesadaran masyarakat terutama majelis taklim yang semakin semarak dengan berbagai kegiatan pengajian di masyarakat. Kondisi tersebut diharapkan dapat menambah kemajuan masyarakat dalam bidang spiritual. Kesadaran yang dimiliki oleh majelis taklim kelurahan Tunggul Wulung perlu didorong dengan pembangunan kegiatan keislaman yang memadai terlebih kegiatan Ramadhan sebagai bulan ibadah.

Kesadaran budaya religius perlu ditanamkan pada masyarakat dan majelis taklim guna menjauhkan mereka dari perilaku yang bertentangan dengan agama terutama bagi generasi berikutnya dengan memberikan pengetahuan agama yang baik serta pembiasaan tindak spiritual bagi para pendatang dan juga mahasiswa sebagai bagian dari masyarakat yang bermukim di sekitar Tunggul Wulung.

Persoalan yang kerap muncul diantara cara penyajian kegiatan agama yang monoton dan kurang menarik sehingga animo masyarakat untuk berpartisipasi kurang direspon dengan baik. Melalui kegiatan pembinaan ini, diharapkan tercipta keinginan yang kuat dalam mendorong semangat religius dengan penyajian materi pengajian yang menarik dan sesuai dengan realita serta mendorong partisipasi 
aktif untuk mempertahankan semangat menuntut ilmu sebagaimana yang diajarkan dalam agama.

Pemahaman keagamaan yang cukup akan menjadi modal berharga untuk menjaga generasi mendatang yang proaktif dalam membina kerukunan umat Islam dan mencegah terjadinya sikap yang bertentangan dengan agama Islam. Masyarakat kini yang memanfaatkan media sosial dengan dampak negatifnya, akan menambah riuhnya problematika religiusitas masyarakat modern. Oleh karena itu, diharapkan majelis taklim sebagai corong untuk membangun masyarakat yang peduli pengetahuan agama serta pola kehidupan agamis dapat tercipta dengan sempurna.

\section{B. Metode Pendampingan}

Metode yang dipergunakan dalam pengabdian ini adalah PAR. Participatory Action Research (PAR) merupakan sebuah bentuk penelitian yang berfungsi melibatkan peran stakeholders untuk ikut serta dalam menganalisa dan melakukan tindakan bersama secara langsung untuk merubah tatanan menjadi lebih baik dan tentunya memungkinkan dilakukan bentuk perubahan yang signifikan dalam masyarakat. Dalam pada itu, diperlukan sebuah telaah kritis untuk membuka kembali kronologi sebuah tatanan baik dari sudut pandang sosial, politis, kontektual, maupun budaya yang dapat mempengaruhi suatu tatanan itu dilakukan.

Adapun kegiatan Participatory Action Research yang dilakukan dalam pengabdian ini adalah dengan melakukan berbagai bentuk kajian keagamaan dan kebahasaan untuk membangun budaya religius berkarakter Islami yang didasarkan pada heterogenitas masyarakat yang terdiri dari kaum asli, pendatang dan komunitas mahasiswa yang tentunya terjadi kompleksitas kegiatan kemasyarakatan. Berlandaskan hal tersebut, maka pembangunan masyarakat yang religius menjadi harapan masyarakat disamping pengetahuan agama yang mencukupi juga perilaku keberagamaan yang efektif dan optimal. 


\section{Hasil dan Pembahasan}

Kegiatan yang dilakukan dalam pengabdian ini dalam bentuk kajian keagamaan dan kebahasaan yang dilakukan secara rutin setiap dua minggu sekali walaupun kegiatan rutin majelis taklim dilakukan secara mingguan. Kajian ini dilakukan oleh tim pengabdian yang dilakukan melalui ceramah keagamaan dengan dikaji sebuah kitab yang berkaitan dengan ibadah mahdhah dan haid bagi wanita.

Pembinaan kajian keagamaan yang dilakukan dalam riset ini adalah dengan memberikan penguatan nilai keagamaan melalui kajian kitab kuning yang dilakukan oleh tim dengan membahas kajian tematik yang sesuai dengan kebutuhan masyarakat. Disamping itu, pembinaan melalui simulasi praktik keagamaan yang dilakukan untuk memberikan penjelasan yang tepat tentang pelaksanaan kegiatan keagamaan. Hal ini sebagaimana disampaikan oleh ketua Majelis Taklim Ibu Hj, Nur Chasanah sebagai berikut:

"Masyarakat Kelurahan Tunggul Wulung dikenal sebagai masyarakat yang agamis namun hakikatnya kurang dalam hal penguasaan materi keagamaan, sehingga kerap kali mereka kumpul dan gemar mengikutinya untuk menambah wawasan keagamaannya"1

Kondisi masyarakat setempat cenderung agamis seiring dengan hadirnya kaum pendatang yang silih berganti, hal ini kerap terjadi khususnya di masyarakat perkotaan yang lebih mengandalkan pengetahuan agama melalui kajian di masjid dan pengajian yang diselenggarakan oleh sebuah organisasi masyarakat. Pelaksanaan pembinaan kajian keagamaan ini dilakukan dalam bentuk pengajian kitab kuning yang menjadikan sebuah perkampungan selayaknya pondok pesantren yang umumnya ustadz atau ustadzah yang datang untuk memberikan penyuluhan tersebut.

Secara etimologis bahwa kajian Islam merupakan sebutan Indonesia untuk istilah Dirasah Islamiyah yang dalam peristilahan barat dikenal dengan Islamic

\footnotetext{
${ }^{1}$ Sumber: Hasil Wawancara dengan Ketua Majelis Taklim Nailul Muna Ibu Hj. Nur Chasanah pada 23 Agustus 2019
} 
Studies. Dalam perkembangannya, pemikiran manusia tentang agama yang berpandangan bahwa aturan agama tidak boleh dirubah yang akan mendatangkan dosa bagi orang yang hendak merubahnya. Oleh karena itu, tatanan hidup beragama harus dilakukan secara serius agar tidak terjerumus menjadi perbuatan yang mendatangkan kerugian pada masa mendatang².

Kajian keagamaan Islam sejalan dengan pengetahuan tentang bahasa Arab yang notabene menjadi bahasa pengantar ilmu-ilmu ke-Islam-an. Penerapan kajian keagamaan akan memberikan arah yang jelas di masyarakat terkait dengan tuntunan kehidupan yang harmonis dan islami. Untuk mewujudkan hal itu, berbagai cara kerap dilakukan untuk membangun wawasan keagamaan yang cukup.

Nurcholish Madjid menuturkan bahwa agama tidak hanya berisi kepercayaan kepada hal-hal yang ghaib dan pelaksanaan ritual-ritual tertentu, namun juga cerminan tingkah laku manusia yang senantiasa berbuat baik yang dilakukan untuk mengharap ridho Allah Swt. Berdasarkan hal itu, maka agama meliputi keseluruhan tingkah laku dalam hidup bersama dengan membentuk manusia yang utuh serta berbudi luhur beserta istiqomah percaya dan iman kepada Allah Swt yang disertai rasa tanggung jawab atas dirinya di hari kemudian ${ }^{3}$.

Pelaksanaan rutinitas Islami tidak hanya sekedar melakukan ibadah mahdhah atau murni, namun juga melakukan ibadah sosial dalam bentuk interaksi dan berbuat baik kepada sesama. Kunci perbuatan baik diantaranya komitmen untuk berbudi luhur dan menjaga hubungan yang baik kepada orang lain. Islam mengajarkan penganutnya untuk melaksanakan tuntunan dalam al-Qur'an dan meneladani perbuatan Rasulullah Saw serta mempelajari agama melalui berbaga metode yang diberikan. Upaya meneladani perjuangan Rasulullah Saw tidak akan

${ }^{2}$ Asnawan. Kontribusi Kajian Keagamaan Dalam Sosiologi Islam. Jurnal Nuansa. Vol (13)No. 2 Juli-Desember 2016. Hlm. 268

${ }^{3}$ Roibin. Relasi Agama \& Budaya Masyarakat Kontemporer. (Malang: UIN Maliki Press. 2009). Hlm. 75 
tercapai tanpa ada sungguh-sungguh dalam membina masyarakat, sebagaimana disampaikan oleh Takmir Masjid sebagai berikut:

"Hakikatnya para jama'ah aktif untuk menjalankan shalat berjama'ah, namun keaktifan tersebut tidak diimbangi dengan pengetahuan sehingga tidak mengetahui siapa yang bisa dianut dan bagaimana menganutnya. Oleh karena itu, upaya keteladanan menjadi hal utama dalam menyampaikan ajaran keagamaan"4

Sebagaimana dijelaskan oleh ketua takmir tersebut, maka pesan keagamaan akan mudah tersampaikan di kalangan masyarakat setempat jika lebih banyak dilakukan kegiatan berkelanjutan dan memberikan nilai keteladanan dalam membangun budaya religi. Masyarakat setempat hakikatnya menyadari akan pentingnya pemahaman agama, namun kesadaran tersebut tidak seimbang dengan wawasan yang cukup untuk memperbaiki kesalahan yang kerap terjadi. Penerapan metode keteladan sebagaimana dilakukan oleh Rasulullah Saw merupakan hal yang lazim dalam mengajarkan nilai beragama.

Metode keteladanan telah dilakukan oleh Rasulullah Saw sebagai upaya untuk menanamkan karakter yang dapat diikuti secara langsung oleh para sahabat dalam menyebarkan dakwah Islamiyah yang sangat berdampak baik bagi tumbuh kembang kemajuan Islam di tanah Arab dengan keseriusan dalam mentaati dan melaksanakan setiap tindakan nyata dalam sikap karakter yang berbudaya.

Kajian yang dilakukan dalam pengabdian masyarakat ini dalam bentuk pengajian yang dilakukan pada majelis ta'lim kelurahan Tunggul Wulung yang dengan melakukan pengajian kitab Uyunul Masa-il Linnisa' yang menggambarkan bagaimana persoalan wanita itu perlu dibahas dengan berbagai persoalan yang dialami oleh kaum wanita. Sebagaimana ditunjukkan dalam gambar atau foto berikut ini:

\section{9}

${ }^{4}$ Sumber: Hasil Wawancara dengan ketua Takmir Masjid pada tanggal 20 Agustus 


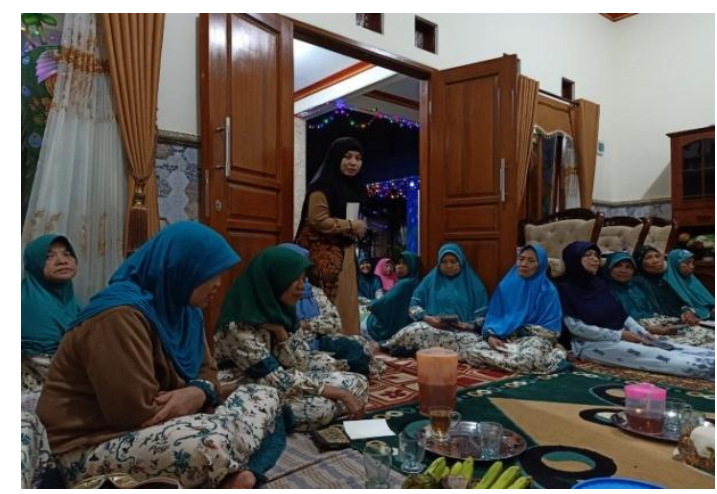

Kajian keagamaan pada majelis taklim Nailul Muna

Sementara itu, kajian fiqih dilakukan dengan kitab Fathul Qarib yang mengimbangi dari sisi pengertian Thaharah dan tata cara bersuci sebagai bagian dari hal yang harus dilakukan pasca haid, begitu juga pemahaman tentang shalat yang kerap identik dengan persoalan wanita di masa haid dimana larangan untuk melakukannya pada masa tersebut. Dalam pada itu, pendalaman dan pembinaan kajian agama dilakukan dalam bentuk kajian sebagaimana telah dijelaskan sebelumnya dan dibubuhi pengenalan materi bahasa Arab.

Jalaluddin Rahmat, dalam bukunya Islam Alternatif telah menunjukkan betapa besar perhatian agama Islam dalam masalah-masalah sosial dengan mengajukan lima alasan,yaitu ${ }^{5}$;

a. Al-Qur'an dan kitab-kitab Hadits memberikan proporsi pembahasan masalah sosial atau dikenal dengan Muamalah lebih dominan dibanding dengan pembahasan yang lainnya.

b. Kenyataan ilmiah yang dijelaskan dalam Islam bahwa jika ditemukan urusan ibadah berbarengan dengan urusan muamalah yang dianggap lebih penting, maka ibadah dapat diperpendek atau ditangguhkan di waktu lainnya sebagaimana pentingnya seseorang melaksanakan kewajiban bepergian, maka shalat dapat dikumpulkan dan diringkas dalam dua shalat.

5 Jalaluddin Rahmat. Islam Alternatif. (Bandung: Mizan. 1986). Hlm.48 
c. Ibadah yang lebih berorientasi kepada aspek-aspek kemasyarakatan maka akan diberikan pahala yang lebih besar seperti jama'ah dibandingkan dengan ibadah sendiri.

d. Orientasi Islam yang tidak menghegemoni dalam memberikan hukuman atas perbuatan melanggarnya. Seperti halnya melanggar ibadah puasa, bersenggama di siang Bulan Ramadhan dan lain sebagainya, maka kafaratnya diberikan salah satunya dengan porsi yang berkaitan dengan masalah sosial.

e. Jaminan agama Islam tentang pentingnya ibadah sosial yang diberikan pahala yang lebih besar daripada ibadah sunnah.

Pembinaan mental spiritual memberikan angin segar bagi segenap masyarakat muslim yang mengenal tentang wawasan Islami yang dapat dilakukan salah satunya dengan majelis taklim untuk penguasaan keyakinan dalam beri'tiqad dan berperilaku yang mengedepankan sosial.

Sebagai bagian dari rutinitas kegiatan pengabdian masyarakat berkelanjutan, maka tim pengabdian memberikan nama kepada majelis ta'lim yang beranggotakan 100 jama'ah dengan nama Nailul Muna yang diketuai oleh $\mathrm{Hj}$. Nur Chasanah yang memprogram setiap kegiatan majelis ta'lim dengan melanjutkan pengajian yang sudah digagas oleh tim pengabdian yang tidak hanya berisikan pertemuan dan pembacaan istighasah secara berjama'ah.

Pembinaan masyarakat dalam bentuk kajian keagamaan jelas terwujud program keberlanjutan yang membekali masyarakat dalam membentengi warga Tunggul Wulung untuk bersama sadar religi dengan pendampingan generasi menuju masyarakat yang berkarakter Islami. Bersamaan dengan itu, majelis ta'lim yang dibentuk oleh tim pengabdian ini memberikan celah pencegahan masyarakat dari kelemahan terhadap pemahaman agama yang memadai di tengah derasnya problematika yang mendera masyarakat di era modern. Hal ini sebagaimana disampaikan oleh ketua majelis Taklim sebagai berikut: 
"Tujuan pembinaan majelis taklim ini untuk menambah wawasan keberagamaan di kalangan masyarakat ini, serta menekankan kepada generasi muda untuk terlibat secara intens untuk terciptanya masyarakat yang berkarakter religius dan jauh dari salah persepsi" 6

Penanaman karakter religi tidak akan dapat diperoleh kecuali dengan pembinaan dari tokoh agama kepada segenap masyarakat muda untuk terbentuknya masyarakat yang beradab. Dalam pada itu, untuk memberikan nuansa agama maka perlu dibentuk budaya yang mencerminkan identitas masyarakat dan terarahnya masyarakat muda setempat.

Kajian keagamaan yang dibungkus dalam bentuk majelis taklim memiliki manfaat yang besar, dimana semua ide dan keinginan dapat disampaikan dan dipola sedemikian rupa guna terciptanya suasana agamis dan ajang untuk bersilaturrahmi dimana Islam memberikan kesempatan seluas-luasnya untuk saling mengunjungi dan menghormati tamu untuk terciptanya hubungan manusia yang harmonis.

Majelis dan ta'lim berasal dari bahasa Arab yang mencerminkan tempat berkumpul dan mempelajari ilmu. Kajian yang dilaksanakan dalam majelis ta'lim ini berguna untuk memperkuat keyakinan dan meluruskan tata cara beribadah dan menggembleng semangat berusaha untuk beribadah secara maksimal. Dalam pada itu, kegiatan ini berjalan di pedesaan, namun kini juga hadir di perkotaan yang memiliki ciri khas yang berbeda.

Majelis ta'lim merupakan ajang berbagi pengetahuan, informasi dan ilmu baik itu berupa ilmu agama maupun ilmu pengetahuan yang berwujud keterampilan yang dilakukan secara berulang-ulang sehingga makna dapat ditangkap secara masif dan membekas di benak para audiens serta terciptanya transformasi pengetahuan yang bermanfaat berupa amal shaleh yang mengalir

${ }^{6}$ Sumber: Hasil Wawancara dengan Ketua Majelis Taklim Nailul Muna Ibu Hj. Nur Chasanah pada 23 Agustus 2019 
untuk mengharapkan ridho Allah Swt serta tertanamnya akhlak yang kokoh? Pelaksanaan drilling dalam pembinaan kajian keagamaan akan membentuk pola keagamaan yang menunjang peradaban suatu bangsa.

Transformasi pengetahuan agama melalui prosesi majelis ta'lim memberikan pemahaman secara praktis dimana perkumpulan akan memberikan dorongan secara mutawatir dalam membina dan membimbing masyarakat menuju ajaran yang sejati. Bentuk pembelajaran agama melalui majelis ta'lim tersaji berbeda bergantung motif yang dilakukan oleh para muallim dalam mentransformasi kajian agama.

Majelis ta'lim juga perlu menggunakan kitab atau buku yang sesuai dengan kemampuan muta'allim. Kitab yang digunakan dapat berupa buku yang berbahasa Indonesia ataupun kitab yang berbahasa Arab. Bahkan tidak menutup kemungkinan, para mu'allim membuat semacam diktat atau modul sebagai materi ajar bagi muta'allim ${ }^{8}$.

Kondisi masyarakat majelis ta'lim Tunggul Wulung begitu antusias dalam belajar agama, namun kondisi demikian tidak diimbangi dengan pengetahuan yang cukup dengan minimnya tokoh agama yang mumpuni untuk mewujudkan ekspektasi masyarakat tersebut. Dalam kajian agama yang diterapkan dalam bingkai kajian keagamaan dan kebahasaan yang diwujudkan pada masyarakat, antusiasme warga tampak dimana walaupun pengabdian ini dilakukan oleh pihak kampus, namun suasana riuh dan ramai tepat berjalan seperti biasanya, hal ini menandakan bahwa kegiatan pengabdian masyarakat ini digemari oleh segenap masyarakat.

Adapun bentuk materi yang diajarkan dalam majelis ta'lim sebagaimana disampaikan oleh Tuti Alawiyah terbagi menjadi lima kategori sebagai berikut: 1) Majelis ta'lim yang hanya menjadi tempat berkumpul dan silaturrahmi dengan melantunkan shalawat berjama'ah dengan menghadirkan seorang penceramah, 2)

\footnotetext{
${ }^{7}$ Helmawati. Pendidikan Nasional dan Optimalisasi Majelis Ta'lim: Peran Aktif Majelis Ta'lim Meningkatkan Mutu Pendidikan. (Jakarta: Rineka Cipta. 2013). Hlm. 85-86 ${ }^{8}$ Helmawati. Ibid. Hlm. 98
} 
Majelis ta'lim yang hanya mengajarkan ilmu dan keterampilan dasar membaca alQur'an dan kajian fiqih dasar, 3) Majelis ta'lim yang mengajarkan tentang Fiqh, Tauhid, Akhlak yang diajarkan oleh seorang muballigh yang disertai tanya jawab, 4) Majelis ta'lim yang mengajarkan ilmu agama dengan menggunakan kitab sebagai pegangan yang dibumbui dengan ceramah, dan 5) Majelis ta'lim dimana materi disampaikan dengan ceramah dan diberikan teks per teks kepada jama'ah, sementara itu materi disajikan secara aktual berdasarkan kondisi terkini ${ }^{9}$.

Bentuk-bentuk majelis ta'lim sebagaimana dijelaskan di atas, memberikan pengertian bahwa majelis ta'lim tidak statis dengan penyajian dalam bentuk kajian rutin yang jauh dari suasana dinamis. Pengajian melalui ceramah yang dihadirkan langsung juga masih diminati oleh masyarakat terlebih pemateri begitu antusias dan menjadi idola di kalangan masyarakat sekitar. Permasalahan masyarakat bertambah banyak, maka pemecahan problem di masyarakat lebih diutamakan dalam membentuk karakter yang Islami dengan mengedepankan nuansa ta'lim yang berguna menambahkan pengetahuan agama.

Masyarakat Tunggul Wulung yang tersaji melalui pengabdian masyarakat khususnya di majelis ta'lim diberikan dalam bentuk pengajian kitab yang disampaikan oleh tim pengabdi untuk membangun budaya religi terhadap masyarakat untuk memberikan pencerahan terhadap persoalan agamis dalam bentuk pendalaman mental spiritual.

Pembangunan mental spiritual tidak akan berjalan maksimal selama tidak ada dukungan dari masyarakat itu sendiri untuk membina warganya menjadi muslim yang taat dan berbakti kepada orang tua dengan tetap menjaga hubungan sesama manusia yang menjadi bagian dari perilaku baik.

Interaksi keagamaan dalam sebuah masyarakat tidak selalu seimbang dengan wawasan yang dimiliki oleh warga setempat. Berbagai kegiatan keagamaan yang kerap dilakukan oleh masyarakat Tunggul Wulung dengan segala

${ }_{9}$ Tuti Alawiyah. Strategi Dakwah di Lingkungan Majelis Taklim.(Bandung: Mizan. 1997). Hlm. 10 
aktivitasnya mencerminkan kehidupan keagamaan yang baik dimana kajian rutin telah dilakukan dengan baik. Kajian sebagaimana dimaksud turut andil dalam membesarkan budaya religi yang sejatinya menjadi idaman segenap masyarakat Tunggul Wulung.

Pemberdayaan masyarakat muda harus digalakkan guna membentuk generasi yang akan menjadi generasi penerus yang menjadi andalan pada masa yang akan datang. Seiring dengan minimnya tokoh sentral yang mampu memberikan pengaruh agar tercipta masyarakat yang berkarakter religius, maka perlu kiranya dilakukan pengkaderan sedini mungkin agar budaya religius masyarakat tidak lenyap pada saatnya nanti. Oleh karena itu, berikut foto kegiatan pengabdian pada masyarakat majelis ta'lim Nailul Muna dalam upaya menjaga kader masyarakat dengan kajian keagamaan:
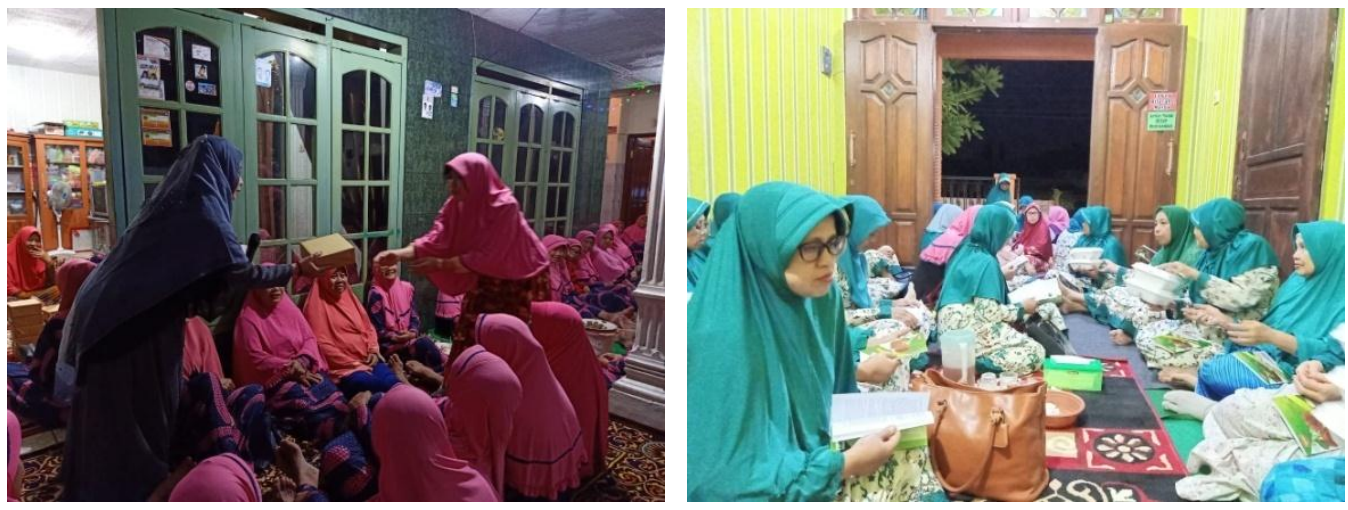

Suasana kegiatan pengabdian masyarakat pada majelis ta'lim Nailul Muna

Pembentukan karakter Islami yang tercermin dalam bentuk kajian keagamaan dan kebahasaan perlu dilakukan dalam bentuk pendalaman materi yang tersaji secara praktis dengan lebih banyak pendampingan akan memberikan pengaruh yang signifikan terhadap kualitas keagamaan yang memadai guna terciptanya suasana keagamaan yang diinginkan dalam berkehidupan yang baik.

Masyarakat yang heterogen kerap kali dengan hadirnya kaum pendatang yang ikut mewarnai variasi pola hidup yang beragam. Dalam pada itu, masyarakat Tunggul Wulung dekat dengan wilayah kampus yang membuatnya menjadi 
masyarakat yang tercermin melalui kaum terpelajar yang mau tidak mau harus ikut serta dalam mengikuti perkembangan zaman.

Keberagamaan atau religiusitas dapat diwujudkan dalam berbagai sisi kehidupan manusia. Aktivitas beragama tidak hanya terjadi ketika seseorang melakukan perilaku ritual (beribadah), tetapi juga ketika melakukan aktivitas lain yang didorong oleh kekuatan supranatural. Bukan hanya yang berkaitan denga aktivitas yang tampak dan dapat dilihat dengan mata, tetapi juga aktivitas yang tidak tampak dan terjadi dalam hati seseorang. Karena itu, keberagamaan seseorang akan meliputi berbagai macam sisi atau dimensi ${ }^{10}$.

Kehidupan agamis melalui pembinaan keagamaan memerlukan upaya yang sungguh-sungguh dari segenap lapisan masyarakat yang tercermin dalam perilaku hidup sehari-hari. Kondisi ini relatif menjadi jalan menuju kesuksesan berkehidupan yang bermartabat dengan tetap memegang teguh semangat gotong royong untuk bantu membantu mewujudkan masyarakat yang memiliki budaya religi dan disertai produk akhir berupa karakter Islami yang kuat.

Pemberdayaan masyarakat membutuhkan adanya pemahaman budaya yang melekat pada mereka. Pembangunan budaya dapat dilakukan terlebih pada masyarakat yang religius dimana sisi-sisi agamis dapat diterapkan dalam berinteraksi secara harmonis berbasis karakter Islami. Dalam pada itu, budaya religius dapat membentuk masyarakat yang berkarakter demi tercapainya keluarga dan warga yang mencerminkan nilai-nilai Islami.

Dalam tataran nilai, budaya religius dapat terlaksana dengan munculnya semangat berkorban, persaudaraan, rasa saling tolong menolong serta pembangunan tradisi etis dalam berkehidupan yang baik. Sementara itu dalam tataran perilaku, budaya religius ini dapat tercermin dalam tradisi ibadah shalat

${ }^{10}$ Muhaimin dkk. Paradigma Pendidikan Islam. (Bandung: PT Remaja Rosdakarya. 2011). Hlm. 293 
berjamaah, rajin bershadaqah, belajar bersama serta perilaku mulian lainnya11. Semangat yang didasari oleh dorongan pembanguna budaya religius, akan memberikan dampak yang sangat besar dalam kehidupan.

Tataran nilai dan perilaku jika diamalkan dalam pola hidup yang dinamis, maka akan memberikan jalan keluar terhadap setiap dinamika yang ada dalam masyarakat. Dalam pada itu, budaya religi dapat berpengaruh terhadap pembangunan spiritual baik dalam pendidikan maupun ilmu lain yang prosesnya dapat dilihat dalam kehidupan sehari-hari.

Berdasarkan keterangan di atas, maka budaya religius merupakan cara pengembangan spiritualitas dalam pendidikan yang diharapkan terwujudnya peserta didik dalam menjadikannya bagian dari masyarakat yang semakin memperkuat keimanan dan ketaqwaan serta memperdekat hubungan dengan Sang Khalik ${ }^{12}$. Pembangunan manusia dengan segala dinamikanya akan membentuk budaya religi jika diimbangi dengan semangat spiritualitasnya.

Pembinaan kajian keagamaan yang dilakukan dalam pengabdian masyarakat ini diwujudkan dalam bentuk pengajian atau ceramah baik melalui kajian kitab kuning dan juga ceramah yang dilakukan untuk memberikan wawasan keagamaan yang memadai. Untuk memperkuat pendalaman agama, maka pengabdian ini dilakukan dengan pendalaman kebahasaan Arab yang diramu di dalam proses pengabdian untuk mengenalkan dan mempraktikkan beberapa kosakata atau mufrodat yang dipakai dalam kitab yang dikaji dalam proses pengabdian masyarakat.

Dalam pada itu, keimanan dan ketaqwaan yang terbina di kalangan masyarakat muslim, akan tampak dengan pengamalan tradisi yang turun temurun

11 Lailil Fatmawati. Implementasi Budaya Religius Dalam Pembinaan Mental Mahasiswi D-III Kebidanan di Akademik Kebidanan Sakinah Pasuruan. (Surabaya: UINSA. 2018). HIm. 30

${ }^{12}$ Djoko Hartono dan Tri Damayanti.Mengembangkan Spiritual Pendidikan. (Surabaya: Jagad Alimussirry. 2016). Hlm. 130 
dengan dalil dan dasar yang jelas dan benar untuk diturunkan kepada generasi penerus yang secara langsung akan menyambungkan tonggak kepemimpinannya.

Dalam menjalankan syariah sebagai hukum Islam, maka hukum tersebut ditetapkan oleh Allah Swt bagi setiap hamba-hamba-Nya untuk mengarungi anugerah yang diberikan Allah Swt. Pencapaian pemahaman syariah menjadi sebuah kewajiban bagi seluruh umat muslim guna terciptanya Islam Rahmatan lil 'Alamin.

Syariah diartikan sebagai hukum yang ditetapkan oleh-Nya yang diperuntukkan bagi hamba-Nya dalam mengimani dan mengamalkan setiap keyakinannya untuk menjalani hidup di dunia. Secara garis besar, syariah difahami untuk dapatnya menjalankan rukun-rukun yang ada dalam Islam secara spesifik melalui tata cara yang telah diturunkan kepada manusia dengan perantara Rasulullah Saw yang terangkum dalam ilmu Fiqih yang mencakung ibadah dan tuntunannya yang disertai doa ${ }^{13}$.

Keberlangsungan syari'ah menjadi perjalanan sejarah bagi perjuangan Rasulullah Saw dalam menjalankan da'wahnya.Dalam pada itu, tradisi yang turun temurun dari nenek moyangnya seakan silih berganti dalam mewariskan ajaran agama kepada keturunannya. Di kelilingi oleh masyarakat yang dikenal dengan zaman Jahiliyah, Rasulullah Saw memperkenalkan betapa pentingnya pendidikan serta pembentukan budaya Religius untuk mewujudkan masyarakat yang berperadaban.Dengan demikian, majelis taklim dilakukan sebagai upaya pembinaan masyarakat melalui bentuk pengajian dan pendalaman materi keagamaan kepada masyarakat.

Sebagaimana dijelaskan oleh Tuti Alawiyah bahwa salah satu bentuk majelis ta'lim dapat dilakukan dengan mengajarkan ilmu agama dengan menggunakan kitab sebagai pegangan yang dibumbui dengan ceramah. Keilmuan agama yang disajikan oleh tim pengabdian dilakukan dua hal yaitu ceramah terhadap materi

13 Nasiruddin Razzak. Membina Masyarakat Islam. (Bandung: Al-Maarif. Tth). Hlm. 
kewanitaan dan ibadah mahdhah serta pengajian kitab yang akan memperkuat keyakinan dan pola ibadah yang berkembang baik dalam menjaga irama keyakinan beragama.

Pembinaan yang dilakukan dalam setiap program pengabdian dapat dilaksanakan pada suatu masyarakat yang membutuhkan proses berfikir yang akan mengembangkan peran serta masyarakat dalam ikut serta membangun kebersamaan dalam bersama-sama mengembangkan interaksi dalam bentuk material maupun immaterial yang terwujud melalui program pengabdian.

Berbeda halnya dengan pemberdayaan masyarakat yang dilakukan oleh perangkat desa dimana kegiatan yang diselenggarakan merupakan satuan program yang telah menjadi kewajiban pembinaan oleh pemerintah untuk kesejahteraan masyarakat yang dalam hal ini terwujud dalam pembinaan keagamaan dan pendidikan. Dalam pada itu, pembinaan mental spiritual yang diselenggarakan dalam pengabdian ini berbentuk kajian keagamaan yang berfungsi untuk membantu pengembangan wawasan keagamaan dan kebahasaan masyarakat melalui kajian rutin selama proses pengabdian maupun pasca dilaksanakan pengabdian.

Program yang telah dijalankan oleh tim pengabdian ini berwujud pendalaman wawasan keagamaan dengan mengkaji kitab Uyunul Masa-il Linnisa' yang sangat bermanfaat untuk menambah wawasan bagi kaum wanita terutama anggota majelis ta'lim yang berkaitan dengan permasalahan wanita dan terkait dengan ibadah yang harus dilakukan dan tidak boleh dilakukan ketika mengalami persoalan kewanitaan. Oleh karena itu, penguasaan permasalahan kontemporer perlu mendapat tempat di kalangan masyarakat Tunggul Wulung yang notabene memiliki ghirah yang tinggi untuk belajar.

Untuk memberikan pemahaman dan pendalaman materi yang memadai dan kontinyu, maka tim pengabdian akan berpartisipasi aktif dalam melanjutkan pembinaan kajian keagamaan yang telah dilaksanakan secara rutin. Oleh karena itu, kajian kitab akan dilaksanakan tiap dua minggu sekali sekaligus memberikan 
wawasan baru terhadap setiap permasalahan yang dialami oleh masyarakat di era modern. Lurah dalam pandangannya memberikan apresiasi terkait peningkatan budaya religi pada warganya dengan mengatakan:

"Masyarakat begitu antusias dan merespon positif hadirnya pembinaan ini, terlebih jamaah majelis taklim yang turut mensukseskan agenda mulia ini. Dalam pada itu, pembentukan karakter Islami yang menjadi cita-cita pembinaan ini begitu tampak dengan meningkatnya kualitas masyarakat dalam menjalankan peran agamanya"14

Antusiasme masyarakat Tunggul Wulung khususnya masyarakat anggota majelis taklim begitu tinggi dan selalu hadir serta memenuhi ruangan tuan rumah dalam mempelajari agama. Oleh karena itu, tim pengabdi akan melaksanakan kegiatan pengajian secara rutin pasca kegiatan pengabdian dengan beberapa tema yang dibutuhkan terkait dengan permasalahan wanita yang sangat dibutuhkan oleh segenap masyarakat kelurahan Tunggul Wulung.

Kegiatan pengabdian yang dilakukan pasca program pengabdian bertujuan untuk mendampingi pendalaman keagamaan yang berupa kajian keagamaan untuk terciptanya kompetensi masyarakat dalam bidang keagamaan agar terbentuk budaya religi yang berkarakter Islami dengan menjaga etika dan perilaku yang santun serta menghargai perbedaan yang tercermin dalam pola kehidupan masyarakat yang Islami.

Kajian ini secara berkelanjutan akan dilakukan setiap dua minggu sekali tepatnya pada hari rabu mengikuti pertemuan rutin majelis ta'lim Nailul Muna yang baru saja terbentuk penamaan terhadap majelis ta'lim tersebut. Keseragaman dan keistiqomahan dalam menjalankan tradisi dan budaya religi perlu dipupuk secara masif agar tidak berkembang budaya yang tidak baik bahkan mengisi dengan kegiatan yang bermanfaat yang dapat memberikan dorongan keagamaan yang memadai.

${ }^{14}$ Sumber: Hasil wawancara kepada Lurah Tunggul Wulung Bapak Budiono pada tanggal 24 Agustus 2019 
Dalam sejarah Islam, Rasulullah Saw telah mencatatkan pola pendidikan Islam yang baik dan santun dimana tradisi Jahiliyah dirubah sedikit demi sedikit sehingga tidak mengusik pola kehidupan yang dinamis. Dalam pada itu, tantangan kaum Quraisy begitu besar dikarenakan prestasi yang ditunjukkan oleh Rasulullah Saw dalam mempengaruhi perubahan di masyarakat sekitar. Sofyan Sauri menuturkan bahwa keberhasilan Rasulullah Saw dalam mendidik sahabatnya menunjukkan hasilnya dengan kualitas dan karakter yang tampak serta munculnya rasa rindu akan kebenaran, semangat menuntut ilmu dan jaya dengan agama Islam yang mana mereka bersimpuh seraya menangis untuk mendekatkan diri kepada-Nya di malam harinya dan berjihad di siang harinya untuk melawan kemusyrikan, kekafiran dan kedzaliman. Rasulullah Saw pun senantiasa memerintahkan kepada kebaikan dan melarang berbuat jahat terhadap sesama dan terlebih agar menebar kasih sayang15.

Kebaikan yang digemakan oleh Rasulullah Saw tiada habisnya dimana kelembutan dalam bersikap serta tidak menebar permusuhan menjadi kunci keberhasilan Rasulullah Saw dalam menjadikan umat yang terbaik. Dalam pada itu, umat terbaik harus senantiasa memberikan contoh dengan memberikan perintah untuk berbuat baik dan mencegah untuk berbuat buruk. Kepiawaian Rasulullah Saw dalam berda'wah dan menyampaikan risalahnya tidak lepas dari tantangan dan rongrongan kaum yang tidak menyukainya dengan harapan pesan da'wah berhenti untuk dilakukan.

Ada lima ciri yang harus diperhatikan oleh seorang muslim yang menjalankan akhlaknya, diantaranya: 1) akhlak tersebut menjadi kepribadian yang tertanam kuat dalam jiwa seseorang, 2) perbuatan akhlak merupakan perbuatan yang dilakukan dengan spontan dan tanpa pemikiran terlebih dahulu, 3) perbuatan akhlak dilakukan dengan tanpa paksaan dan tidak direkayasa dikarena

15 Sofyan Sauri. Filsafat dan Teosofat Akhlak (Kajian Filosofis dan Teosofis tentang Akhlak, Karakter, Nilai, Moral, Etika, Budi Pekerti, Tata Krama, Sopan Santun). (Bandung: Rizqi Press. 2011). HIm. 89 
muncul dari lubuk hatinya, 4) perbuatan akhlak berfungsi untuk meninggikan kalimat Allah Swt yang telah dinyatakan dalam al-Qur'an dan al-Hadits ${ }^{16}$.

Perbuatan akhlak menjadi ciri khas Rasulullah Saw dalam menjalankan da'wahnya sehingga dapat diterima oleh banyak kalangan. Akhlak yang dilakukan oleh seorang muslim juga mencerminkan pembiasaan budaya yang dapat diturunkan kepada generasi berikutnya agar tercipta budaya dan tradisi yang turun temurun dengan makna yang tersampaikan kepada generasi penerus tersebut.

\section{Kesimpulan}

Pembinaan kajian yang dilakukan dalam riset ini dilakukan dalam bentuk pengajian keagamaan Islam, pemberian simulasi serta tindak lanjut sebagai bagian dari pendampingan masyarakat secara intens. Karakter yang dilakukan dalam kajian ini adalah penguatan budaya religi yang memberikan kesadaran akan agama demi terciptanya masyarakat yang beradab. Adapun hasil pembinaan dan kajian ini adalah sebagai berikut:

Pertama; wawasan keagamaan dan kebahasaan masyarakat Majelis Ta'lim di unggul Wulung Kecamatan Lowokwaru Kota Malang tergolong sedang atau standar. Namun keseimbangan wawasan tersebut tidak sebanding dengan ghirah yang tinggi terhadap partisipasi dalam menuntut ilmu agama yang mana antusiasme mengikuti kegiatan keagamaan melalui majelis ta'lim sangat diperhatikan.

Kedua; pembinaan dan pendampingan kajian keagamaan dan kebahasaan yang dilakukan dalam program pengabdian ini dilakukan dalam bentuk pengajian kitab Uyunul Masa-il Linnisa' disertai dengan ceramah yang banyak berkaitan dengan masalah kewanitaan dan ibadah mahdhah yang perlu menjadi perhatian oleh segenap warga kelurahan Tunggul Wulung. Berdasarkan hal tersebut,

\footnotetext{
16Yuliharta. Pembentukan Karakter Islami Dalam Hadits dan Implikasinya Pada Jalur Pendidikan Non Formal. Potensia: Jurnal Kependidikan Islam. Vol (4) 2. Juli Desember 2018. HIm. 219
} 
Pembinaan Kajian Keagamaan Berbasis Karakter Islam Pada Majelis Taklim Lowokwaru pembentukan budaya religi semakin semarak dengan perwujudan karakter Islami yang melekat pada diri masyarakat dalam rangka membekali dan membangun generasi yang sadar religi.

Oleh karena itu, pembinaan kajian keagamaan pada Majelis Ta'lim Kelurahan Tunggul Wulung memberi celah betapa perwujudan semangat atas responsif masyarakat terhadap pendalaman agama begitu baik, maka didoronglah suatu kegiatan keagamaan yang dapat memberikan wawasan pembentukan karakter Islami seperti yang diharapkan. Dalam pada itu, pembenahan segala aspek perlu menjadi perhatian untuk menjadikan warga kelurahan Tunggul Wulung benarbenar menjadi masyarakat percontohan dalam kegiatan keagamaan.

\section{Daftar Rujukan}

Alawiyah, Tuti. Strategi Dakwah di Lingkungan Majelis Taklim. (Bandung: Mizan. 1997)

Asnawan. Kontribusi Kajian Keagamaan Dalam Sosiologi Islam. Jurnal Nuansa. Vol. 13 No. 2 Juli-Desember 2016

Fatmawati, Lailil. Implementasi Budaya Religius Dalam Pembinaan Mental Mahasiswi D-III Kebidanan di Akademik Kebidanan Sakinah Pasuruan. (Surabaya: UINSA. 2018)

Hartono, Djoko dan Tri Damayanti. Mengembangkan Spiritual Pendidikan. (Surabaya: Jagad Alimussirry. 2016)

Helmawati. Pendidikan Nasional dan Optimalisasi Majelis Ta'lim: Peran Aktif Majelis Ta'lim Meningkatkan Mutu Pendidikan. (Jakarta: Rineka Cipta. 2013)

Muhaimin dkk. Paradigma Pendidikan Islam. (Bandung: PT Remaja Rosdakarya. 2011)

Putri, Rizky Amalia. Pendampingan Anak-Anak Korban Lumpur Lapindo Kelurahan Jatirejo Kec. Porong Sidoarjo. (Surabaya: IAIN SA. 2010)

Rahmat, Jalaluddin. Islam Alternatif. (Bandung: Mizan. 1986)

Razzak, Nasiruddin. Membina Masyarakat Islam. (Bandung: Al-Maarif. Tth) 
Danial Hilmi, Nur Toifah dan Erna Herawati

Roibin. Relasi Agama \& Budaya Masyarakat Kontemporer. (Malang: UIN Maliki Press. 2009)

Sauri, Sofyan. Filsafat dan Teosofat Akhlak (Kajian Filosofis dan Teosofis tentang Akhlak, Karakter, Nilai, Moral, Etika, Budi Pekerti, Tata Krama, Sopan Santun). (Bandung: Rizqi Press. 2011)

Yuliharta. Pembentukan Karakter Islami Dalam Hadits dan Implikasinya Pada Jalur Pendidikan Non Formal. Potensia: Jurnal Kependidikan Islam. Vol (4) 2. Juli Desember 2018 